\title{
広域海面水温の平年偏差に起因した東南アジア 地域における降水および台風特性
}

\author{
小林 彩佳 $1^{*} \cdot$ 山田 朋人 $2 \cdot$ 竹内 大輝 1 \\ 1学生会員 北海道大学大学院工学院（干060-8628 札幌市北区北13条西8丁目） \\ *E-mail:pistaricari@gmail.com \\ 2正会員 北海道大学大学院工学研究院 ( $\overline{0} 060-8628$ 札幌市北区北13条西8丁目)
}

\begin{abstract}
2011年にタイのチャオプラヤー川流域において大洪水が発生した. 同年は年平均2 3個に対して5個の台 風が東南アジア地域に到達しており, その影響で平年の1.6倍の降雨量が同流域にもたらされた. タイ国 を含む東南アジア地域の水文気象場は，太平洋とインド洋の影響を受けていることが指摘されている。本 研究は海面水温と東南アジア地域における降水量及び同地域への台風到達数の関係を明らかにすることが 目的である. 太平洋とインド洋の海面水温の空間分布特性から対象とする64年間を5つのグループに分類 した．2011年を含むグループでは，両海洋の海面水温は全体的に高く，北西太平洋で発生した台風のうち 東南アジア地域への到達率は5つのグループで最も高く, その割合は平年の1.4倍程度多いことがわかった.
\end{abstract}

Key Words : preciptation, sea surface temperature anomary, typhoon, Southeast Asia, ENSO, IOD

\section{1. はじめに}

2011年8月から11月にかけてタイ国チャオプラヤー川 流域において未曾有の大洪水が発生し，死者 813 人，行 方不明者 3 人という甚大な被害となった1). 同年 11 月 14 日 時点では日系企業449社を含む計806社の企業が使用する 7つの工業団地が浸水した。 このことから同洪水はタイ 国だけではなく我が国にも甚大な経済被害をもたらした。 チャオプラヤー川は上流にプミポンダム及びシリキッ トダムを有する。これらの貯水容量はそれぞれ 135 億 $\mathrm{m}^{3}$, 94億 $\mathrm{m}^{3}$ であり，特にプミポンダムは日本最大の貯水量を もつ奥只見ダムの約50倍となる.

タイ国の季節は5 10月の雨季，11 4月の乾季に大別さ れる. 図-1に雨季におけるプミポンダム及びシリキット ダムへの流入量と両ダム流域の合計降水量を示す。大洪 水が発生した2011年は，チャオプラヤー川流域における 降水量はいずれの月においても平年值を上回り, 結果と して雨季の総降水量は2915 mmとなり，平年值の約1.6倍 を記録した。また同年の両ダムの合計流入量は 21.4 億 $\mathrm{m}^{3}$ であり平年值の約2.3倍であった。

その原因として2011年の雨季に襲来した計5個の台風 及び熱帯低気圧による影響が挙げられる(平年では2 3個). とりわけ，6月には台風4号(HAIMA)，7月には台風8号 (NOCK-TEN)の影響で多くの降水量がチャオプラヤー川
流域にもたらされた1).

タイ国を含む東南アジア地域は太平洋とインド洋に挟 まれており，同地域の気候は太平洋におけるEl-Niño, LaNiña現象(El-Niño Southern Oscillation, ENSO)やインド洋にお けるインドダイポールモード現象(Indian Ocean Dipole, IOD)それぞれの影響を受けている.ここでEl-Niño現象と は，太平洋赤道域の日付変更線付近から南米のペルー沿 岸にかけての広い海域で海面水温が平年に比べて高くな る現象を示し，逆に同じ海域で海面水温が平年より低い 状態が続くものがLa-Niña現象である. 一方, IODに関し ては，インド洋東部の海面水温が平年よりも低い状況が 正のIOD，逆にインド洋西部の海面水温が平年よりも低 い状態が負のIODとされている.

Ho et $\mathrm{al}^{2}{ }^{2}$ は北西太平洋で発生した台風が描く経路が長 期的なスケールでどのように変化しているか調心゙，1970 年代後半を境に南シ十海の海面水温の上昇に起因して台 風経路が西方向へ移動したと指摘している. Wang et al. ${ }^{3)}$ はENSOの強さによって熱帯低気圧の経路を分類し, 強 いEl-Niño現象のときに東南アジア地域に多くの熱帯暴風 をもたらすことを示した.このように台風の数とENSO の強さの関係性や，長期的な台風経路の変化など，東南 アジアに来る台風について議論されてきた.

Hong et al. ${ }^{4}$ はIODとENSOの組み合わせによって海面水 温平年偏差のパターンを作成し, それらが東南アジアの 


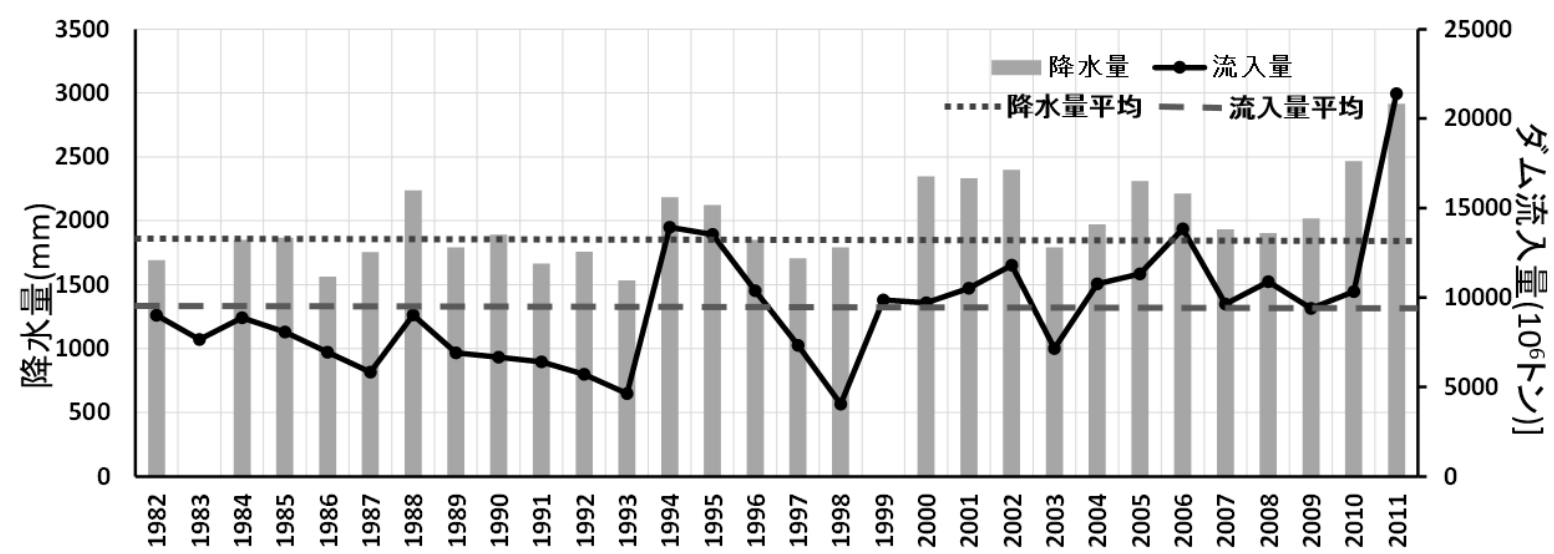

図-1 棒グラフはプミポンダム，シリキットダム流域各地点の雨季合計降水量(mm). 折れ線グラフは両ダムの雨季合計流入量

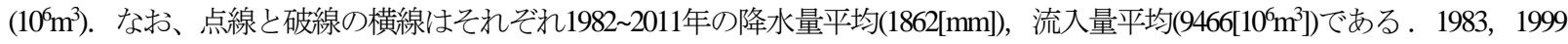
年の降水量は欠損值である. なお，データはタイ王立灌激局からいただいたダム湖への流入データ，ダム流域降水量データ を用いた。

気象場に与える影響を調べ，それらは変則的な大気循環 と関係するENSOに影響をうけることがわかった，同論 文はENSOとIODの組み合わせでパターンを作成したが, 本論文では太平洋及びインド洋の海面水温平年偏差の特 徵の組み合わせによってパターンを作成する．経験的直 交関数展開(Empirical Orthogonal Function analysis,EOF)を用い て太平洋・インド洋のそれぞれの海面水温の特徴を抽出 した後に, クラスタ分析により両海洋の特徽的な空間場 を5つのクラスタに分類した. それぞれについて東南ア ジア地域の各気象場を議論する．2章では使用したデー タ及び解析手法を説明し，3章において分類した海面水 温の空間的特徵，クラスタごとの降水量の地域分布特性, 東南アジア地域での台風経路の特徵について記述する. 最後にまとめを4章に記す。

\section{2. 解析手法・データ}

\section{(1) 解析手法}

タイ国を含む東南アジア地域の雨季の後半に相当する 8 10月について，1948年から2011年の64年間の海面水温 データ(データの詳細は後述)から太平洋及びインド洋の 特徵的な空間場を抽出する.海面水温は64年間の間に 徐々に上昇傾向を有しており，EOFで得られる海面水温 の空間特性にその影響が強く反映してしまう。そこで対 象とする年を中心とする30年間の平年值に対する偏差を 求めた。ただし，データは1948 2011年のみであり 1948 1961, 1997 2011年は対象年を中心にとることができ ない，それらについては，1948 1961年に対して平年值 は1948 1977年の平均值，1997 2011年に対して平年值は 1982 2011年の平均值にするなどその年を含む出来るだ け近傍の平年值を用いてその偏差を算出した.
次に，ENSO及びIODを加味するため，太平洋では東 経120 170度, 北緯5度 南緯5度, インド洋では東経 50 110度，北緯10度〜南緯10 度においてEOFを適用した。

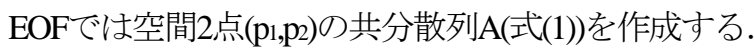

$$
\mathrm{A}=\sum_{n=1}^{N} z\left(n, p_{1}\right) z\left(n, p_{2}\right)
$$

Nは時間方向のデータ数である. 固有值の総和に対寸る Aの固有值の比を寄与率とし, 寄与率が高いものから順 に第mモードとする．累積寄与率が $85 \%$ を超えるモード までを使用し，太平洋では第2モード，インド洋では第3 モードまでを用いた。 これらのモードに対し，クラスタ 解析の一つであるK-means法5によって1948 2011年までの 8 10月のそれぞれの月について5個の似た特徴を持つク ラスタに分類した．K-means法は各クラスタの重心と各 クラスタ内のデータ間における2乗ユークリッド距離の 総和が最小になるようにクラスタを作成する手法である.

$$
\left.\mathrm{F}\left(\left\{C_{k}\right\}\right)=\sum_{k=1}^{K} \sum_{X_{i} \in C_{k}} \overline{(} X_{k}-X_{i}\right)^{2}
$$

Kはクラスタの数, $\mathrm{C}_{\mathrm{k}}$ はクラスタ内の要素, $\mathrm{X}_{\mathrm{k}}-\mathrm{X}_{1}$ は重心 と各要素の距離である. 太平洋及びインド洋それぞれの 海面水温平年偏差の特徽の組み合わせが似ている年の集 合が同じクラスタとして分類される.

\section{(2) 使用したデータ}

a) 海面水温データ

前述のEOFに使用した海面水温データは，The Extended Reconstructed Sea Surface Temperature(ERSST) $)$ データである. 同データの水平解像度は $2^{\circ}$ であり，解析には1948 2011 年の月平均海面水温を用いた。

\section{b) 降水量データ}


降水量データは，Asian Precipitation Highly Re-solved Observational Data Integration Towards Evaluation of the Water Resources(APHRODITE) `) 使用した。同データの水平解像 度は0.25 であり，解析には1951 2007年の日降水量を用 いた.

\section{c)ダム湖への流量データ}

1980年から2011年までのプミポンダムとシリキットダ ム湖への流入量データを用いた。 このデータはタイ国王 立灌溉局が継続的に観測しているものである.

d) 台風データ

国立情報学研究所のデジタル台風データベース到によ って公開されている情報から，北西太平洋で発生した 台風910個と、北西太平洋で発生しかつ東南アジア地域 (東経100 100度，北緯10 20度内)を通過した台風117個を 解析対象とした。

\section{(3) ENSO及びIODの分類手法}

本研究においてENSOはアメリカ海洋大気庁（National Oceanic and Atmospheric Administration）の定義9を用い, Niño3.4の海域(東経120 70度，北緯5度〜南緯5度)におけ る海面水温の平年偏差が $0.5^{\circ} \mathrm{C}$ 以上にときにEl-Niño現象, $-0.5^{\circ} \mathrm{C}$ 以下のときにLa Niña現象，それ以外のときは平年 とした. 一方，IODに関しては，海洋研究開発機構が公 開しているDipole Mode Index(DMI ${ }^{10)}$ を使用した。 DMI と
は1981 2011年までの東インド洋(東経50 70度，北緯10度 〜南緯10度) と西インド洋(東経90 110度，北緯10度〜赤 道)の週ごとの海面水温の差である. このデータセット から1981 2011年を対象としたDMIの3ケ月平均の標準偏 差によって分類した，標準偏差は0.41であり，3ケ月平 均が標準偏差以上の場合は正のIOD, 負の標準偏差以下 の場合は負のIOD，それ以外は平年とした。

\section{3. 結果}

\section{(1) クラスタの分類結果}

表-1は2章に記したEOF及びK-means法により分類され たクラスタを示す. 図-3は同じクラスタに分類された年 における海面水温の平均值の平年偏差を, 表-2にはクラ スタごとにENSO, IODに該当する年数を示す.

表-2をみると，クラスタ 2 クいて該当年のうち $87.5 \%$ がEl-Niño，75.0\%が正のIODに分類されている。 また， クラスタ 20 海面水温はペルー沖から赤道にかけては平 年より高く, 東インド洋では平年より低い。これらはそ れぞれEl-Niño及び正のIODが有す海面水温の特徵と言え よう.

これに対して，クラスタ3の該当年のうち50\%が負の IODである. クラスタ 3 の海面水温はペルー沖から赤道 にかけては平年より冷たく, 東インド洋では平年より暖

表-1 1948 2011年の 64年間を対象としたクラスタ分類結果

\begin{tabular}{|c|c|c|}
\hline クラスタ & \multicolumn{1}{|c|}{ 該当年 } & 年数 \\
\hline クラスタ1 & $1948,1959,1963,1966,1967,1969,1976,1979,1983,1985,1986,1991,2001,2002,2003,2006$ & 16 \\
\hline クラスタ2 & $1949,1961,1965,1972,1977,1982,1987,1994,1997$ & 9 \\
\hline クラスタ3 & $1950,1964,1970,1971,1973,1975,1988,1996,1998,1999,2008,2010$ & 12 \\
\hline クラスタ4 & $1958,1962,1968,1980,1981,1989,1990,1995,2000,2004,2005,2007,2009,2011$ & 14 \\
\hline クラスタ5 & $1951,1952,1953,1954,1955,1956,1957,1960,1974,1978,1984,1992,1993$ & 13 \\
\hline
\end{tabular}
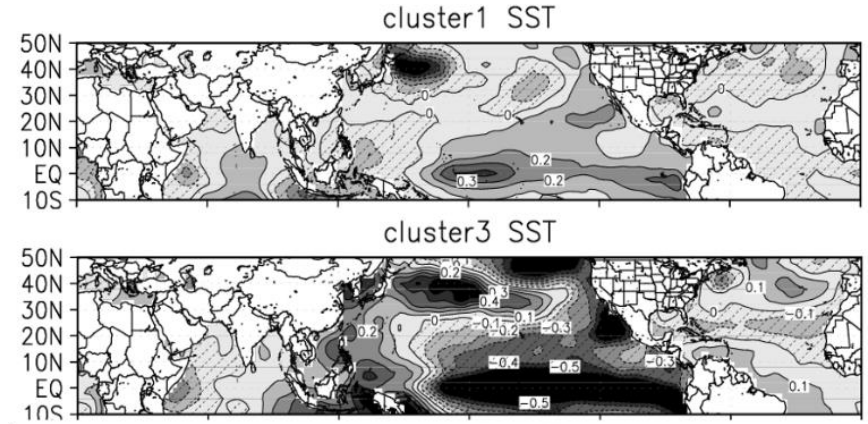

cluster5 SST

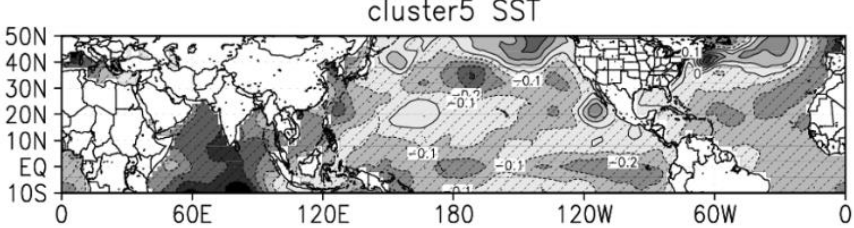

cluster2 SST

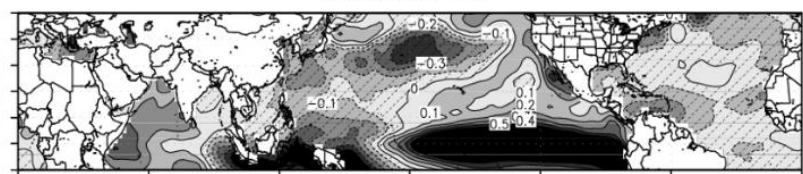

cluster4 SST
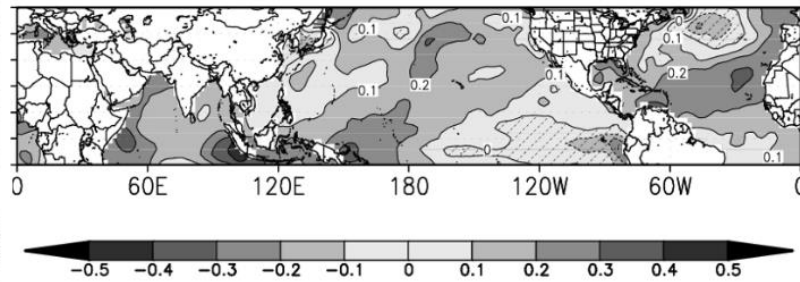

$\left[{ }^{\circ} \mathrm{C}\right]$

図-2 クラスタごとの8 10月における海面水温(Sea Surface Temperature,SST)の平均值の平年偏差 $\left({ }^{\circ} \mathrm{C}\right)$. 斜線部分は負の偏差を示す. な お，平年值は1948 2011年までの8 10月の海面水温の平均值を用いた. 
かい.これらはそれぞれLa-Niña及び負のIODが有す海面 水温の特徵である.

前述の通りクラスタ 2 とではENSO及びIODの該当年 数や海面水温の地域分布からENSO及びIODの特徵が見 て取れる. 一方，2011年はクラスタ4に属し，このクラ スタでは表-2をみるとENSO及びIOD共に異なる特徴が 混在しているものの, 図-2より太平洋，インド洋，大西 洋いずれも全体的に高温偏差という特徵を有する. なお, 2011年の8 10月は2章で述べた分類手法によるとLa-Niña かつ正のIODであった。

\section{(2) クラスタごとの降水量の平年偏差}

図-3はAPHRODITEのデータが存在する1951 2008年に

表-2 クラスタごとの ENSOおよびIODの対応表. ENSO は 1950 2011年, IODは 1982 2011年を対象として分類した.

\begin{tabular}{|l|r|r|r|r|r|}
\hline & cluster1 & cluster2 & cluster3 & cluster4 & cluster5 \\
\hline ENSOサンプル数 & 15 & 8 & 12 & 14 & 13 \\
\hline エルニーニョ年 & 7 & 7 & 0 & 3 & 3 \\
\hline 平年 & 6 & 1 & 3 & 7 & 7 \\
\hline ラニーニャ年 & 2 & 0 & 9 & 4 & 3 \\
\hline IODサンプル数 & 8 & 4 & 6 & 9 & 3 \\
\hline 正のIOD年 & 3 & 3 & 0 & 2 & 0 \\
\hline 平年 & 5 & 1 & 3 & 7 & 2 \\
\hline 負のIOD年 & 0 & 0 & 3 & 0 & 1 \\
\hline
\end{tabular}

\section{(3) クラスタごとの台風襲来数}

2011年にチャオプラヤー川流域を襲った洪水は平年よ りも多く襲来した台風や熱帯低気圧による影響が大きい と指摘されている1). 表-3は1951 2011年の8 10月に北西 太平洋で発生した台風と，同期間に東南アジア地域(東 経100 110度，北緯10 20度内)に到達した台風の個数をそ れぞれクラスタごとに示す.なお，ここで議論する台風 の個数は2章に記したデジタル台風データベースにおい て公開されている基準に準ずるものである。対象期間の

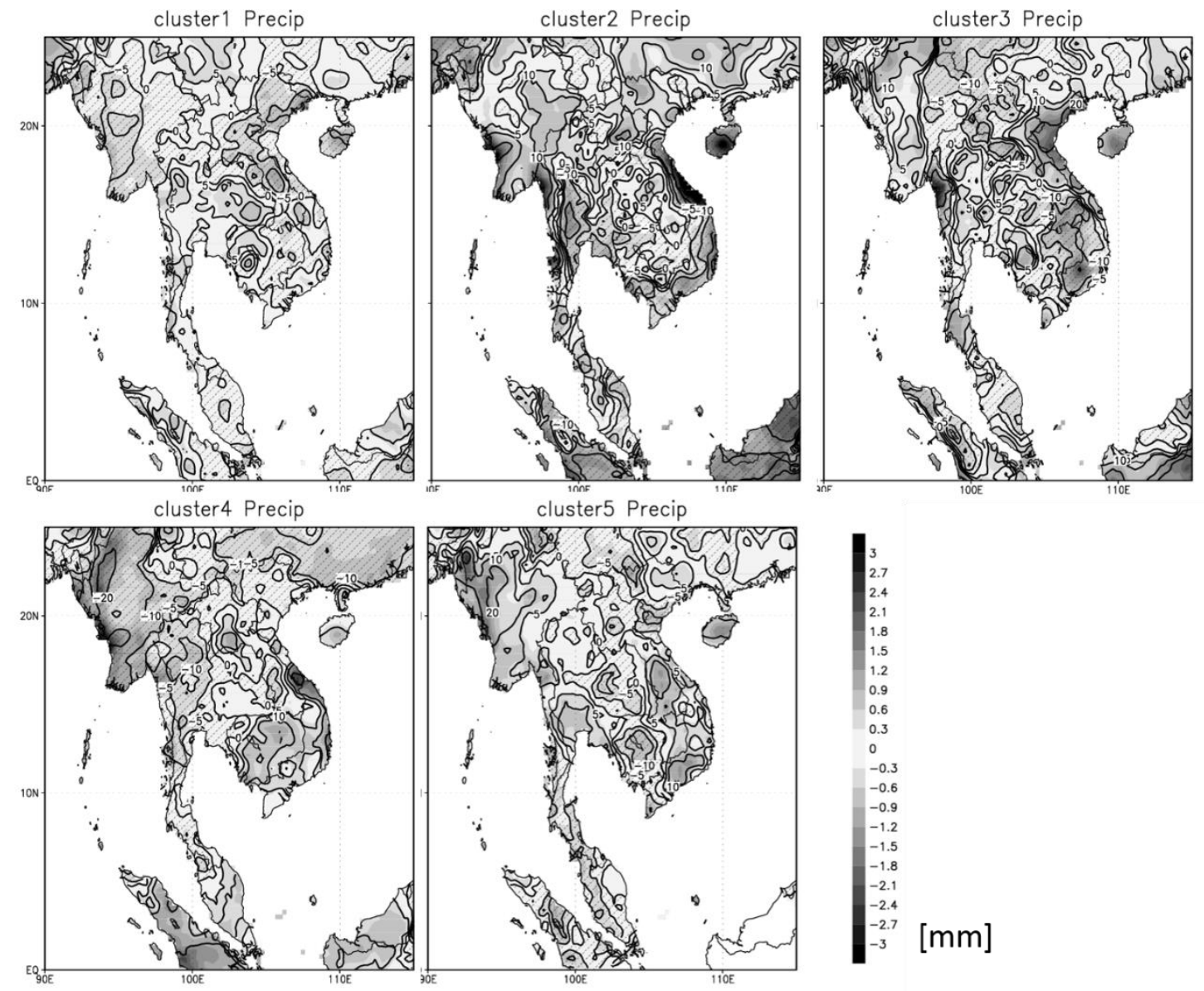

図-3 クラスタごとの8 10月の降水量(mm/day)の平年偏差とその平年值に対する変化率 $(\%)$. 斜線部分は負の偏差を示寸. なお，平 年值は1951 2008年までの8 10月の降水量平均とした. 図中の色は降水量の平年偏差を, 值は变化率をそれぞれ示す. 
8 10月の北西太平洋上では毎年平均で14.9個の台風が発 生している。そのうち同期間に東南アジア地域に到達し た台風の数は平年值で約1.9個であり, 北西太平洋上で 発生した台風の約 $12.8 \%$ あるあ.

2011年を含むクラスタ4において東南アジア地域に襲 来した台風の平均個数は平年值の約1.3倍である2.6個で ある(他クラスタは0.7 1.1倍).またこれは北西太平洋上 で発生する台風のうち約17\%であり，ほかのクラスタ(914\%)よりも大きな值を示している.この結果はクラス タ4の海面水温平年偏差(図-2(d))で現されるように，太 平洋，インド洋及び大西洋において海面水温が平年より
も高い空間分布となるとき，太平洋北西部で発生した台 風が平年よりも東南アジア地域に到達しやすいという特 徵を示唆するものである.

\section{(4) クラスタごとの台風経路}

ここでは台風の詳細な発生箇所，東南アジア地域のど こを通過したかを知るために，台風経路を調べる。なお， 第1章にて台風と熱帯低気圧について述べたが，ここで はトロピカル・サイクロンのうち最大風速が34ノット以 上のものとデジタル台風8にて定義された台風を扱う.

図-4は1951 2011年の8 10月に北西太平洋で発生し,

表-3 1951 2011 年の 8 10 月に北西太平洋(東経 180 度以 西，赤道以北) と東南アジア地域(東経 100 100 度，北 緯 10 20 度内)に到達した台風の平均個数，北太平洋 で発生した台風のうち東南アジア地域に到達した台 風の比率(個)。なお，平年值は 1951 2011年の 8 10月 の台風個数平均とした.

\begin{tabular}{|l|r|r|r|}
\hline & 北西太平洋(個) & 東南アジア(個) & 比率(\%) \\
\hline クラスタ1 & 14.4 & 1.3 & 9.03 \\
\hline クラスタ2 & 16.3 & 2.1 & 12.88 \\
\hline クラスタ3 & 14.4 & 2.0 & 13.89 \\
\hline クラスタ4 & 14.9 & 2.6 & 17.45 \\
\hline クラスタ5 & 15.2 & 1.8 & 11.84 \\
\hline
\end{tabular}

\section{cluster2}

\section{cluster1}
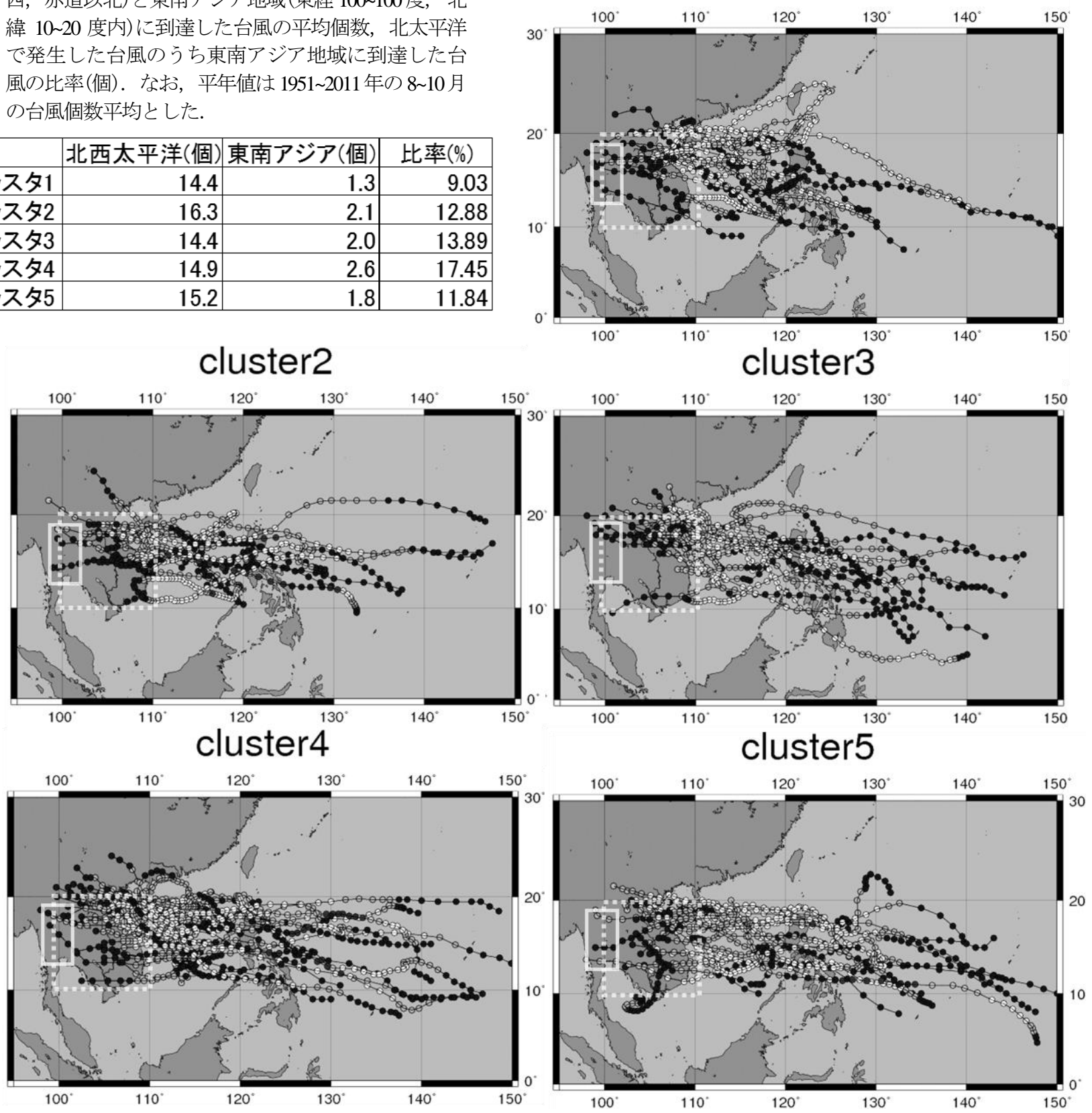

図-4 1951 2011年の8 10月に北西太平洋で発生し，東南アジア地域(東経100 110度, 北緯10 20度内)に到達した台風の個数に到達し た台風の経路．実線で囲まれた部分はおおおよそのチャオプラヤー川流域(東経97 102度，北緯13 18度)，点線で囲まれた部分は 東南アジア地域を示す. 
東南アジア地域(東経100 110度，北緯10 20度内)に到達 した台風の経路をそれぞれクラスタごとに示す.

クラスタ 4の台風は他のクラスタに比べ,北緯 10 20 度 内にほぼ収まる経路を描いている. クラスタ 1 3 は台風 経路が北部に集中しているのに対し,クラスタ 4,5 は北部 に台風が集まる傾向はあるものの領域内全体的に台風が 到達している. また,どのクラスタも東南アジア地域に 到達した台風がチャオプラヤー川流域まで到達するとは 限らない.

\section{4. まとめ}

本研究ではEOFを用いて太平洋及びインド洋のそれぞ れの海面水温の特徵を抽出し, クラスタ分析により両海 洋の特徽的な空間場をいくつかのクラスタに分類した. その後にクラスタごとに東南アジア地域の降水量, 到達 した台風の数, それらの台風の経路を調べた. 2011年の 所属するクラスタ4では, 海面水温が太平洋, インド洋, 大西洋と全体的に平年よりも高温である. また，そのと き北西太平洋で発生し東南アジア地域に到達する台風の 比率が平年よりも1.4倍大きいことがわかった.ただし， 台風の経路をみると東南アジアに到達した台風が必ずし もチャオプラヤー川まで到達するとは限らないとの結果 になった。 これは広域海面水温の空間パターンから準季 節スケールでの東南アジア地域に到達する台風の数を予 測できる可能性を示した.

謝辞：本研究はMEXT/SOUSEI (theme C-i-C), JSPS科研費 15K18118，JCA/JST/SATREPSの成果の一部である. また 図-1で使用したダム湖流入データはタイ王立灌溉局より
頂いたものである.

\section{参考文献}

1) 小森大輔 : 2011 年タイ国チャオプラヤー川大洪水はなぜ 起こったか, バンコク日本人商工会議所 所報 2012.02 p.2-10, 2012.

2) Ho, C. H., J. J. Baik, J. H. Kim, D. Y. Gong, and C. H. Sui : Interdecadal changes in summertime typhoon tracks, J. Climate, 17, pp.1767-1776,2004.

3) Wang, B.and J. C. L. Chan. : How strong ENSO events affect tropical storm activity over the western North Pacific, American Meteorological Society, 2002.

4) Hong, C.C., M. M.Lu, and M. Kanamitsu: Temporal and spatial characteristics of positive and negative Indian Ocean dipole with and without ENSO, JOURNAL OF GEOPHYSICAL RESEARCH, VOL. 113, 2008.

5) Hair,J.F., Anderson, R.E., Tatham, R. L. and Black, W.C.: Multivariate Data Analysis, 5th ed. Prentice-Hall International, 1998.

6) Smith, T.M., R.W. Reynolds, T.C. Peterson, and J. Lawrimore: Improvements NOAAs Historical Merged Land-Ocean Temp Analysis (18802006). Journal of Climate, 21, 2283-2296, 2008.

7) Yatagai, A., K. Kamiguchi, O. Arakawa, A. Hamada, N. Yasutomi and A. Kitoh: APHRODITE: Constructing a Long-term Daily Gridded Precipitation Dataset for Asia based on a Dense Network of Rain Gauges, Bulletin of American Meteorological Society, 2012.

8）北本朝展 : デジタル台風, 国立情報学研究所 HP, (2015.4), http://agora.ex.nii.ac.jp/digital-typhoon

9) Barnston, A.G., M. Chelliah and S.B. Goldenberg;: Documentation of a highly ENSO-related SST region in the equatorial Pacific. AtmosphereOcean, 1997.

10) Saji, N.H., Goswami, B. N., Vinayachandran, P.N. and Yamagata, T:A dipole mode in the tropical Indian Ocean, Nature 401 ,pp.360-363, 1999.

(2015.4.7受付)

\title{
CHARACTERISTICS OF RAINFALL AND TYPHOONS IN SOUTHEAST ASIA ASSOCIATED EITH LARGE-SCALE SEA SURFACE TEMPERATURE ANOMALIES
}

\author{
Ayaka KOBAYASHI ${ }^{1}$, Tomohito J.YAMADA ${ }^{2}$ and Daiki TAKEUCHI ${ }^{1}$ \\ ${ }^{1}$ Graduate school of Engineering, Hokkaido University \\ ${ }^{2}$ Fucalty of Engineering, Hokkaido University
}

This research discuss relationship between sea surface temperature in the Pacific Ocean and the Indian Ocean and climate Southeast Asia. We used Empirical Orthogonal Function analysis and K-means method for analysis and classified 5 group based on the characteristics of sea surface temperature in the Pacific Ocean and the Indian Ocean. Then we investigated precipitation, the number of typhoon and tracks for each group. The group including the year of 2011 has high sea surface temperature in the Pacific Ocean, the Indian Ocean and the Atlantic Ocean. At that time the ratio of the number of the typhoon in the Northwest Ocean Pacific that attack the Southeast Asia is 1.4 times the average one. This research indicate predictability of the typhoon number from large scale sea surface temlperature anomalies. 